\title{
Diana Trzcińska*
}

\section{DECENTRALIZACJA ZADAŃ W SPRAWACH KSZTAŁTOWANIA ŁADU PRZESTRZENNEGO}

Przestrzeń jest nieodłącznym elementem ludzkiego istnienia oraz działania, w sensie przemieszczania się w przestrzeni, integracji z innymi ludźmi w przestrzeni czy po prostu oglądu otaczającej przestrzeni z jakiegoś jej punktu, a zatem stanowi coś więcej niż tylko tło lub kontekst dla istniejących i mających powstać obiektów ${ }^{1}$. Na gruncie prawa planowania i zagospodarowania przestrzennego przestrzeń może być rozumiana jako część powierzchni ziemi ze wszystkimi elementami struktury przestrzennej (fizycznymi, np.: budynki i przyrodniczymi, np.: drzewa, lasy, parki krajobrazowe) na niej się znajdującymi, w tym także przestrzeń morska, będąca przedmiotem regulacji prawnej z punktu widzenia racjonalnego jej kształtowania lub zachowania przy uwzględnieniu bieżących i przyszłych potrzeb społeczeństwa przy użyciu instrumentów charakterystycznych dla prawa administracyjnego ${ }^{2}$.

* Diana Trzcińska - doktor nauk prawnych, Katedra Prawa Gospodarczego Publicznego i Ochrony Środowiska, Uniwersytet Gdański.

1 W. Ratajczak, Ład przestrzenny $i$ ład zintegrowany $w$ planowaniu, prezentacja dostępna na portalu http://uslugipubliczne.pl/db/news_att/1f0e7db3af.pdf (dostęp: 7.11.2018 r.).

${ }^{2}$ Nieco odmiennie M. Woźniak wskazuje na „elementy składowe przestrzeni”, do których zalicza powierzchnię ziemi, wodę, przyrodę, grunty rolne i leśne, zabytki, tereny miast i wsi. Por. M. Woźniak, Interes publiczny jako przesłanka działań organów planistycznych [w:] Przestrzeń i nieruchomości jako przedmiot prawa administracyjnego. Publiczne prawo rzeczowe, red. I. Niżnik-Dobosz, Warszawa 2012, s. 79. 
Przestrzeń charakteryzuje się istotnymi cechami, które determinują objęcie jej określonym zakresem regulacji w przepisach prawa. W piśmiennictwie podkreśla się, że przestrzeń jako swoisty przedmiot unormowań prawnych jest, po pierwsze, dobrem, po drugie szczególnym dobrem, które określa się mianem dobra wspólnego, po trzecie zaś - dobrem limitowanym³ . „Skończony” charakter przestrzeni w sensie możliwości jej wykorzystania sprawia, że sposób jej zagospodarowania podlega regulacji prawnej, ${ }^{4}$, przy czym zasadniczo są to normy należące do obszaru prawa publicznego, ze wszelkimi konsekwencjami z tego faktu wynikającymi w zakresie zasad tego prawa oraz metody regulacji stosunków prawnych. Państwo zaś ogranicza swobodę zagospodarowania przestrzeni w celu ochrony określonych wartości, które mają znaczenie dla realizacji interesu publicznego $^{5}$.

Kształtowanie przestrzeni jawi się w konsekwencji jako istotne zadanie publiczne, którego realizacja wymaga aktywności państwa. Stworzenie podstaw i ram dla gospodarowania przestrzenią, czy to morską, czy lądową, stanowiącą niewątpliwie dobro publiczne, jest treścią owego zadania publicznego, którego realizacja powinna być podporządkowana określonym celom i wartościom. Jednocześnie, o czym mowa już była powyżej, ograniczony charakter przestrzeni wymaga, aby przynajmniej część zadań składających się na kształtowanie przestrzeni związana była z reglamentacją zasad jej wykorzystania ${ }^{6}$.

W odniesieniu do problematyki kształtowania ładu przestrzennego szczególne znaczenie należy przypisać zasadzie pomocniczości, będącej źródłem decentralizacji zadań w tym zakresie (art. 15 ust. 1

3 Zob. np. I. Bogucka, Zagospodarowanie terenów rolniczych w przypadku braku planu miejscowego (zagadnienia wybrane), „Studia Iuridica Agraria” 2012/10, s. 142, oraz T. Kurowska, Własność gruntowa a planowanie przestrzenne $w$ dorobku naukowym Profesora Waleriana Pańki, „Studia Iuridica Agraria” 2012/10, s. 13. Por. też K. Kurczewska, E-partycypacja społeczności lokalnych w planowaniu zagospodarowania przestrzennego [w:] Przestrzeń..., red. I. Niżnik-Dobosz, s. 123.

${ }^{4}$ Por. M. Kotulski, Problemy kształtowania przestrzeni w procesie planowania i zagospodarowania przestrzennego [w:] Przestrzeń..., red. I. Niżnik-Dobosz, s. 37.

${ }^{5}$ Por. M. Kotulski, Problemy... s. 38.

${ }^{6}$ Por. J. Parchomiuk, Nadużycie władztwa planistycznego gminy, ST 2014/4, s. 22. 
Konstytucji RP) ${ }^{7}$. Nie ulega wątpliwości bowiem, że prawidłowość i racjonalność realizacji zadań związanych z kształtowaniem i gospodarowaniem przestrzenią jest uzależniona od przekazania ich z poziomu centralnego (państwa) na poziom regionalny (województwa), a przede wszystkim lokalny (gminy), gdyż decydującym czynnikiem jest w tym zakresie rozeznanie charakterystyki terenu i jej uwarunkowań lokalnych. Więzi społeczne, gospodarcze i kulturowe kształtujące w istotny sposób uwarunkowania przestrzenne danego terenu zapewniają, po myśli art. 15 ust. 2 Konstytucji RP, zdolność wykonywania zadań publicznych w sferze gospodarowania przestrzenią przez poszczególne jednostki podziału terytorialnego kraju w ramach ich kompetencji wyznaczonych w podstawowym w tej mierze akcie normatywnym, tj. ustawie z 27.03.2003 r. o planowaniu i zagospodarowaniu przestrzennym ${ }^{8}$.

Punktem wyjścia jest tu założenie, że podmiotowość publicznoprawna wspólnot samorządowych jest konsekwencją podmiotowości prawnej państwa ${ }^{9}$, a zatem jest uwarunkowana prawnie ${ }^{10}$. Wspólnota taka nabywa władztwo publiczne na podstawie przepisów prawa rangi ustawowej, a w konsekwencji jej prawa do wykonywania określonych zadań publicznych na rzecz wspólnoty lokalnej są pochodną indywidualnych praw podmiotowych członków społeczności lokalnej ${ }^{11}$. Zgodnie z art. 163 Konstytucji RP samorząd terytorialny wykonuje zadania publiczne niezastrzeżone przez Konstytucję RP lub ustawy dla organów innych władz publicznych. Zadania publiczne stanowią natomiast zadania „służące zaspokajaniu potrzeb wspólnot lokalnych,

7 Preambuła Konstytucji Rzeczypospolitej Polskiej jednoznacznie odsyła (w przeciwieństwie do tekstu głównego Konstytucji, w której brak jest odwołań do zasady pomocniczości) do „zasady pomocniczości umacniającej uprawnienia obywateli i ich wspólnot".

${ }^{8}$ Dz.U. z 2018 r. poz. 1945 - dalej jako: u.p.z.p.

9 Zgodnie z art. 16 ust. 2 Konstytucji RP samorząd terytorialny uczestniczy w sprawowaniu władzy publicznej. Przysługującą mu w ramach ustaw istotną część zadań publicznych samorząd wykonuje w imieniu własnym i na własną odpowiedzialność.

${ }^{10}$ Por. W. Jakimowicz, O normatywnych podstawach władztwa planistycznego gminy [w:] Kierunki reformy prawa planowania i zagospodarowania przestrzennego, red. I. Zachariasz, Warszawa 2012, System Informacji Prawnej LEX.

11 W. Jakimowicz, O normatywnych..., z powołaniem na wskazaną tam literaturę. 
służące realizacji dobra wspólnego"12. Katalog tych zadań jest bardzo obszerny, gdyż obejmuje zarówno zadania związane ze świadczeniem usług społecznie użytecznych, zarządzaniem mieniem, ale także z reglamentowaniem dóbr z uwzględnieniem interesu publicznego. Do takich zadań, które bezpośrednio wiążą się z reglamentacją dóbr, należą zadania w sferze planowania i zagospodarowania przestrzennego, gdyż odnoszą się do limitowanego dobra, jakim jest przestrzeń.

Zgodnie z art. 164 ust. 3 Konstytucji RP gmina wykonuje wszystkie zadania samorządu terytorialnego niezastrzeżone dla innych jednostek samorządu terytorialnego. Przy czym, samodzielność w zakresie wykonywania zadań publicznych uznawana jest za podstawowy aspekt samodzielności jednostek samorządu terytorialnego ${ }^{13}$. Zadania publiczne służące zaspokajaniu potrzeb wspólnoty samorządowej są wykonywane przez jednostkę samorządu terytorialnego jako zadania własne (art. 166 ust. 1 Konstytucji RP). Z przepisów Konstytucji RP wynika więc domniemanie kompetencji na rzecz samorządu terytorialnego (w zakresie „istotnej części” zadań publicznych) oraz domniemanie kompetencji na rzecz gminy jako podstawowej jednostki samorządu terytorialnego ${ }^{14}$. W ten sposób samodzielność gminy wiąże się ze sprawowaniem przez nią władztwa administracyjnego w oznaczonym zakresie, będącego wyrazem wyznaczonych jej praw i obowiązków publicznoprawnych. W konsekwencji publiczne prawa podmiotowe gminy i jej obowiązki uzasadniają władztwo publiczne tej wspólnoty samorządowej i wyznaczają jego granice ${ }^{15}$.

Władztwo administracyjne stanowi immanentną cechę administracji publicznej i oznacza "prawo użycia przymusu bezpośredniego przez organy administracji dla zrealizowania ich jednostronnych zarządzeń” ${ }^{16}$. Szerzej rzecz ujmując, jest to pewien „zakres mocy,

${ }_{12}$ Por. Z. Niewiadomski, Planowanie i zagospodarowania przestrzenne. Komentarz, Warszawa 2006, s. 28.

${ }_{13}$ Por. J. Jagoda, Sądowa ochrona samodzielności jednostek samorządu terytorialnego, LEX 2011, dostęp: System Informacji Prawnej LEX.

14 J. Jagoda, Sądowa...

15 W. Jakimowicz, O normatywnych...

${ }^{16}$ Por. E. Ochendowski, Prawo administracyjne. Część ogólna, Toruń 2004, s. 24. 
atrybutów władczych i zawiadowczych", w jaki wyposażona jest administracja ${ }^{17}$. Podmiotem władztwa jest państwo jako suweren, jednak może ono „cedować” to władztwo na inne podmioty sprawujące w oznaczonym zakresie administrację publiczną, co ma miejsce w szczególności w odniesieniu do jednostek samorządu terytorialnego. Jednakże należy mieć na uwadze, że w takiej sytuacji gmina, wyposażona w atrybut, jakim jest władztwo administracyjne, nie jest samodzielna w stosunku do suwerena, jakim jest państwo, gdyż jej mandat do wykonywania tego władztwa jest wtórny względem suwerena i nie przekreśla faktu, że działa ona w imieniu „państwa”"

Rozwinięcie powyższej materii w kwestii praw i obowiązków publicznoprawnych jednostek samorządu terytorialnego i ram przysługującego im władztwa administracyjnego znajduje się zatem w szczególności w przepisach dotyczących samorządów terytorialnych w Polsce, w odniesieniu do gmin - w ustawie z 8.03.1990 r. o samorządzie gminnym $^{19}$. Zgodnie z art. 6 u.s.g. do zakresu działania gmin należą wszystkie sprawy o znaczeniu lokalnym niezastrzeżone ustawami na rzecz innych podmiotów. Zgodnie zaś z art. 7 u.s.g. do zadań własnych gminy należy zaspokajanie zbiorowych potrzeb wspólnoty, przy czym zadania te w szczególności obejmują sprawy wskazane w art. 7, w tym na pierwszym miejscu - sprawy ładu przestrzennego ${ }^{20}$. Przysługujące gminie domniemanie kompetencji w sprawach o znaczeniu lokalnym w zakresie realizacji zadań publicznych rozciąga się zatem również na kwestie planowania i zagospodarowania przestrzennego, obejmując sprawy ładu przestrzennego, oraz zorganizowania sieci gminnych dróg, ulic, mostów, placów, wodociągów i zaopatrzenia w wodę, kanalizacji, urządzeń sanitarnych, wysypisk i unieszkodliwiania odpadów komunalnych, zaopatrzenia w energię elektryczną i cieplną oraz gaz itp. Ponadto, zgodnie z art. 40 ust. 1 u.s.g., na podstawie upoważ-

17 J.S. Langrod, Instytucje prawa administracyjnego. Zarys części ogólnej, Kraków 2003, s. 228, cyt. za: W. Jakimowicz, O normatywnych...

18 Tak W. Jakimowicz, O normatywnych...

19 Dz.U. z 2016 r. poz. 446 ze zm. - dalej jako u.s.g.

${ }^{20}$ Por. Ł. Pośpiech, Poglądy orzecznictwa sądowoadministracyjnego i doktryny $w$ kwestii studium gminnego i jego charakteru prawnego [w:] Przestrzeń..., red. I. Niżnik-Dobosz, s. 156. 
nień ustawowych gminie przysługuje prawo stanowienia aktów prawa miejscowego obowiązujących na obszarze gminy, stanowiących akty prawa miejscowego w rozumieniu art. 94 Konstytucji RP. Jak wskazuje Z. Niewiadomski, te dwie cechy, tj. konstytucyjne domniemanie kompetencji gminy w sprawach lokalnych oraz gwarantowana konstytucyjnie samodzielność gminy w tych sprawach, tworzą systemowe ramy upoważniające do analizy uprawnień i obowiązków gmin w zakresie planowania i zagospodarowania przestrzennego ${ }^{21}$.

Decentralizacja zadań w sferze kształtowania ładu przestrzennego konkretyzuje się na poziomie ogólnym w treści cytowanego na wstępie art. 3 u.p.z.p. i wynikającym z niego podziale zadań w tym zakresie pomiędzy poszczególne jednostki samorządowe. Zgodnie z treścią tego przepisu, poza gminami, do których należy kształtowanie i prowadzenie polityki przestrzennej na jej terenie, do zadań samorządu powiatu należy prowadzenie, w granicach swojej właściwości rzeczowej, analiz i studiów z zakresu zagospodarowania przestrzennego, odnoszących się do jego obszaru. Kształtowanie i prowadzenie polityki przestrzennej na obszarze związku metropolitalnego (obszarze metropolitalnym) należy do zadań związku metropolitalnego, jeżeli został utworzony, natomiast kształtowanie i prowadzenie polityki przestrzennej w województwie, w tym uchwalanie planu zagospodarowania przestrzennego województwa, należy do zadań samorządu województwa.

Plan zagospodarowania przestrzennego województwa jest dokumentem planistycznym z zakresu kształtowania polityki przestrzennej, którego moc wiążąca i charakter nie zostały precyzyjnie określone w przepisach prawa. Z przepisów ustawy o planowaniu i zagospodarowaniu przestrzennym wynika, że plan ten sporządza się dla obszaru w granicach administracyjnych województwa (art. 39 ust. 2 u.p.z.p.) ${ }^{22}$,

${ }^{21}$ Por. Z. Niewiadomski, Planowanie..., s. 29.

${ }^{22}$ Zgodnie z treścią art. 39 u.p.z.p. w planie zagospodarowania przestrzennego województwa uwzględnia się ustalenia strategii rozwoju województwa oraz rekomendacje i wnioski zawarte w audycie krajobrazowym oraz określa się w szczególności: podstawowe elementy sieci osadniczej województwa i ich powiązań komunikacyjnych oraz infrastrukturalnych, w tym kierunki powiązań transgranicznych; system obszarów 
a także że uchwala go sejmik województwa (art. 42 ust. 1 u.p.z.p.). Przepisy wskazują także elementy, które należy uwzględnić w planie oraz jego podstawowe elementy treściowe (art. 39 ust. 3-5 u.p.z.p.). Mimo publikacji w dzienniku urzędowym nie jest to jednak akt prawny o powszechnie obowiązującym charakterze, lecz co najwyżej wewnętrznie obowiązującym i wiążącym inne organy administracji w zakresie wyraźnie uregulowanym w ustawie o planowaniu i zagospodarowaniu przestrzennym ${ }^{23}$.

Ustalenia planu zagospodarowania przestrzennego województwa są wprowadzane do miejscowego planu, co następuje jednak dopiero po uzgodnieniu marszałka województwa z wójtem (burmistrzem, prezydentem miasta) terminu realizacji celu publicznego o znaczeniu ponadlokalnych i warunków wprowadzenia ich do planu miejscowego ${ }^{24}$.

chronionych, w tym obszary ochrony środowiska, przyrody i krajobrazu kulturowego, ochrony uzdrowisk oraz dziedzictwa kulturowego i zabytków oraz dóbr kultury współczesnej; rozmieszczenie inwestycji celu publicznego o znaczeniu ponadlokalnym; granice i zasady zagospodarowania obszarów funkcjonalnych o znaczeniu ponadregionalnym oraz, w zależności od potrzeb, granice i zasady zagospodarowania obszarów funkcjonalnych o znaczeniu regionalnym; obszary szczególnego zagrożenia powodzią; granice terenów zamkniętych i ich stref ochronnych oraz obszary występowania udokumentowanych złóż kopalin i udokumentowanych kompleksów podziemnego składowania dwutlenku węgla. $\mathrm{W}$ planie zagospodarowania przestrzennego województwa uwzględnia się ustalenia koncepcji przestrzennego zagospodarowania kraju oraz programy, o których mowa w art. 48 ust. 1 u.p.z.p. W planie zagospodarowania przestrzennego województwa umieszcza się te inwestycje celu publicznego o znaczeniu ponadlokalnym, które zostały ustalone w dokumentach przyjętych przez Sejm Rzeczypospolitej Polskiej, Radę Ministrów, właściwego ministra lub sejmik województwa, zgodnie z ich właściwością. Dla miejskiego obszaru funkcjonalnego ośrodka wojewódzkiego uchwala się plan zagospodarowania przestrzennego miejskiego obszaru funkcjonalnego ośrodka wojewódzkiego jako część planu zagospodarowania przestrzennego województwa.

${ }^{23} \mathrm{M}$. Szewczyk wskazuje, że pod względem charakteru prawnego plan zagospodarowania przestrzennego województwa ani nie przynależy do konstytucyjnie określonego systemu źródeł prawa powszechnie obowiązującego, ani też nie jest typowym aktem prawotwórczym kierownictwa wewnętrznego zob. M. Szewczyk [w:] Prawo zagospodarowania przestrzeni, red. Z. Leoński, M. Szewczyk, M. Kruś, Warszawa 2012, s. 87.

${ }^{24}$ Zgodnie $\mathrm{z}$ art. 44 u.p.z.p. ustalenia planu zagospodarowania przestrzennego województwa wprowadza się do planu miejscowego po uprzednim uzgodnieniu terminu realizacji inwestycji celu publicznego o znaczeniu ponadlokalnym i warunków wprowadzenia ich do planu miejscowego. Uzgodnienia powyższe przeprowadza marszałek 
W konsekwencji na wszystkich szczeblach podziału terytorialnego kraju (oprócz powiatu, gdzie sporządzane są wyłącznie analizy i studia z zakresu zagospodarowania przestrzennego) będziemy mieli do czynienia z prowadzeniem polityki przestrzennej związanej z wydawaniem aktów planistycznych pozbawionych charakteru powszechnie obowiązującego, natomiast wyłącznie w gminie charakterystyczne będzie zarówno prowadzenie polityki przestrzennej (i wydawanie w tym zakresie aktów wewnętrznie obowiązujących - studiów uwarunkowań i kierunków zagospodarowania przestrzennego), jak i ustalanie zasad przeznaczenia terenu w formie aktów o charakterze powszechnie obowiązującym - przepisów prawa miejscowego. Powyższe oznacza jednocześnie, że zadania związane z kształtowaniem przestrzeni w istotnej części realizowane są przez samorządy terytorialne: samorząd województwa i samorząd gminny, przy czym pozycja gminy jest w tym zakresie kluczowa (o czym mowa poniżej), co nie umniejsza roli samorządu województwa w tej sferze, który w szczególności sporządza wyżej opisany plan zagospodarowania przestrzennego województwa ${ }^{25}$ (art. 42 u.p.z.p.).

Odnosząc się do charakterystyki roli samorządu gminy w realizacji omawianego zadania publicznego, należy wskazać na treść art. 3 ust. 1 w powiązaniu z art. 4 u.p.z.p., który stanowi podstawę konstrukcji, określanej w doktrynie mianem „władztwa planistycznego gminy”, akcentując jednocześnie jej szczególną pozycję jako jednostki samorządu terytorialnego w realizacji zadań związanych z kształtowaniem przestrzeni w Polsce. Koncepcja ta ma charakter teoretyczny i wypracowana została w doktrynie prawa planowania i zagospodarowania prze-

województwa z wójtem, burmistrzem albo prezydentem miasta. Koszty wprowadzenia ustaleń planu zagospodarowania przestrzennego województwa do planu miejscowego oraz zwrotu wydatków na odszkodowania, o których mowa w art. 36 u.p.z.p., a także kwoty przeznaczone na pokrycie zwiększonych kosztów realizacji zadań gminnych są ustalane w umowie zawartej pomiędzy marszałkiem województwa a wójtem, burmistrzem albo prezydentem miasta.

25 Zgodnie z art. 38 u.p.z.p. organy samorządu województwa sporządzają plan zagospodarowania przestrzennego województwa, prowadzą analizy i studia oraz opracowują koncepcje i programy odnoszące się do obszarów i problemów zagospodarowania przestrzennego odpowiednio do potrzeb i celów podejmowanych w tym zakresie prac, a także sporządzają audyt krajobrazowy. 
strzennego ${ }^{26}$. W orzecznictwie i doktrynie można spotkać także pojęcia zbliżone, jak „samodzielność planistyczna gmin”, pokrywające się w zasadniczym kształcie z pojęciem władztwa planistycznego ${ }^{27}$. Zasada władztwa planistycznego gminy definiuje zasadniczą kompetencję tej jednostki samorządu terytorialnego w sferze kształtowania przestrzeni pod warunkiem działania na podstawie i w granicach prawa, potwierdzając jednocześnie fakt realizacji tych zadań w sposób zdecentralizowany, oparty na zasadzie pomocniczości. Bardziej szczegółowo zasada ta definiowana jest jako „ustawowe upoważnienie organów gminy do określania w sposób jednostronny i władczy przeznaczenia gruntów położonych na obszarze działania gminy oraz określania zasad ich zagospodarowania, niezależnie od tego, do kogo te grunty należą i niezależnie od woli władających tymi gruntami”28. Z. Niewiadomski wskazuje, że ,władztwo planistyczne gminy oznacza przekazanie gminie kompetencji w zakresie przeznaczania i ustalania zasad zagospodarowania terenu $\mathrm{z}$ możliwością zastosowania w tej mierze formy aktu prawnego wiążącego [...], a w przypadku braku planu - w drodze decyzji o warunkach zabudowy i zagospodarowania terenu"29.

Omawiana kategoria prawna, traktowana jednocześnie jako jedna z podstawowych zasad prawa planowania i zagospodarowania przestrzennego, wiąże się bezpośrednio z sytuacją prawną gminy - jej szczególnym statusem ustrojowym, a w konsekwencji można ją analizować z perspektywy podmiotowości publicznoprawnej gminy ${ }^{30}$.

Unormowania prawne w zakresie przypisania gminie wykonywania zadań publicznych niezastrzeżonych dla organów innych władz

${ }^{26}$ Określenie to powszechnie stosowane jest w nauce prawa niemieckiego. Do polskiej literatury prawniczej wprowadził je Z. Niewiadomski - zob. Z. Niewiadomski, D. Strębicka, Zagospodarowanie przestrzenne, Warszawa-Zielona Góra 1994, s. 11. Por. też Z. Niewiadomski, Planowanie przestrzenne. Zarys systemu, Warszawa 2002, s. 86; Z. Leoński, M. Szewczyk, M. Kruś, Prawo..., s. 56 i n.; T. Bąkowski, Wpływ przemian ustrojowych $w$ Polsce na prawo zagospodarowania przestrzennego, ST 2000/1-2, s. 148 i n.

${ }_{27}$ Więcej na temat różnic zob. Z. Niewiadomski, Planowanie przestrzenne..., s. 34-35 oraz 82 i n.

28 Tak M. Szewczyk [w:] Z. Leoński, M. Szewczyk, M. Kruś, Prawo..., s. 59.

29 Tak Z. Niewiadomski, Planowanie przestrzenne..., s. 87.

${ }^{30}$ Por. W. Jakimowicz, O normatywnych... 
publicznych, w tym także w omawianej sferze planowania i zagospodarowania przestrzennego, są konsekwencją cytowanych wyżej uregulowań konstytucyjnych dotyczących samodzielności gminy i związanych z tą samodzielnością - zasadą domniemania kompetencji realizacji zadań publicznych przez gminę, rozwijanych w przepisach rangi ustawowej. Jednocześnie należy podkreślić, że samodzielność gminy jest odzwierciedleniem jej statusu jako zdecentralizowanego podmiotu administracji publicznej, wyposażonego we władztwo administracyjne (publiczne) w zakresie określonym w Konstytucji RP i ustawach ${ }^{31}$.

Zgodnie z cytowanym już art. 3 ust. 1 u.p.z.p. kształtowanie i prowadzenie polityki przestrzennej na terenie gminy, w tym uchwalanie studium uwarunkowań i kierunków zagospodarowania przestrzennego gminy oraz miejscowych planów zagospodarowania przestrzennego, należy do zadań własnych gminy. Przy czym, zgodnie $z$ art. 4 ust. 1 u.p.z.p., ustalenie przeznaczenia terenu, rozmieszczenie inwestycji celu publicznego oraz określenie sposobów zagospodarowania i warunków zabudowy terenu następuje w miejscowym planie zagospodarowania przestrzennego. Natomiast w przypadku braku miejscowego planu zagospodarowania przestrzennego okre-

${ }^{31}$ Wśród wielu teorii na temat samodzielności gmin w znaczeniu konstytucyjnych, których szczegółowe omawianie w tym miejscu jest niemożliwe ze względu na ramy niniejszego opracowania, wskazać należy na teorię państwową, zgodnie z którą istota samorządu polega na wykonywaniu praw zwierzchnich, odstąpionych przez państwo korporacjom samorządowym jako ich własne prawo. W tak rozumianym samorządzie upatruje się skrystalizowania publicznego prawa podmiotowego, określanego jako możność rozporządzania władzą publiczną, a uznanie osobowości publicznoprawnej jednostek samorządowych łączy się z ich prawem do samodzielnego sprawowania części administracji publicznej. Tak J. Jendrośka, Teorie samorząu terytorialnego [w:] Prawo administracyjne, red. J. Boć, Wrocław 2004, s. 185. Jednocześnie należy zauważyć, na co wskazuje J. Jakimowicz, że sposób wykonywania władztwa publicznego przez państwo jest określany przez jego organy ustawodawcze. Natomiast, zakres władztwa publicznego jednostek samorządu wynika z regulacji ustawowych, a więc aktów, na które organy gmin bezpośredniego wpływu nie mają. W konsekwencji zakres tego władztwa i sposób jego realizacji jest pochodną upoważnień w tym zakresie „scedowanych” na organy samorządu w takim kształcie i formie, jakie wynikają z przepisów obowiązującego prawa, stanowionego na szczeblu „państwowym”. O ich ramach decyduje ustawodawca, wyznaczając granice samodzielności gminy oraz kompetencje jej organów. Por. W. Jakimowicz, O normatywnych... 
ślenie sposobów zagospodarowania i warunków zabudowy terenu następuje w drodze decyzji o warunkach zabudowy i zagospodarowania terenu, przy czym:

1) lokalizację inwestycji celu publicznego ustala się w drodze decyzji o lokalizacji inwestycji celu publicznego;

2) sposób zagospodarowania terenu i warunki zabudowy dla innych inwestycji ustala się w drodze decyzji o warunkach zabudowy (art. 4 ust. 2 u.p.z.p.).

Powyższe przepisy wskazują zatem, że do zadań własnych gmin należy kształtowanie i prowadzenie polityki przestrzennej na terenie gminy. Głównym instrumentem kształtowania tej polityki są miejscowe plany zagospodarowania przestrzennego, będące, zgodnie $\mathrm{z}$ art. 14 ust. 8 u.p.z.p., aktami prawa miejscowego. Przedmiotem miejscowych planów zagospodarowania przestrzennego jest ustalenie przeznaczenia terenu, rozmieszczenie inwestycji celu publicznego oraz określenie sposobów zagospodarowania i warunków zabudowy terenu. Z kolei studium uwarunkowań i kierunków zagospodarowania przestrzennego stanowi dokument polityki przestrzennej gminy, który nie jest aktem prawa miejscowego, jednak jego ustalenia „są wiążące dla organów gminy przy sporządzaniu planów miejscowych" (art. 9 ust. 4 i 5 u.p.z.p.). W braku planów narzędziem służącym określeniu sposób zagospodarowania i warunków zabudowy terenu jest decyzja o warunkach zabudowy. Z woli ustawodawcy zatem decyzja o warunkach zabudowy jest aktem, który nie zastępuje planu miejscowego, bo ten jest podstawowym narzędziem kształtowania przestrzeni w gminie, jednak wypełnia lukę powstałą wskutek jego braku. Przepisy powyższe w połączeniu $\mathrm{z}$ art. 12 ust. 1, art. 20 ust. 1, art. 51 ust. 1 pkt 1 i 2 oraz art. 60 ust. 1 u.p.z.p. ${ }^{32}$ potwierdzają zasadę o generalnej właściwości gmin

${ }^{32}$ Zgodnie $\mathrm{z}$ art. 12 ust. 1 u.p.z.p. studium uchwala rada gminy. Według art. 20 ust. 1 u.p.z.p. plan miejscowy uchwala rada gminy. $Z$ kolei art. 51 ust. 1 pkt 1 i 2 u.p.z.p. stanowi, że w sprawach ustalenia lokalizacji inwestycji celu publicznego decyzje wydają w odniesieniu do: 1) inwestycji celu publicznego o znaczeniu krajowym i wojewódzkim - wójt, burmistrz albo prezydent miasta w uzgodnieniu z marszałkiem województwa; 2) inwestycji celu publicznego o znaczeniu powiatowym i gminnym - wójt, burmistrz albo prezydent miasta, zaś stosownie do art. 60 ust. 1 u.p.z.p. decyzję o warunkach zabudowy wydaje, z zastrzeżeniem ust. 3, wójt, burmistrz albo prezydent miasta. 
w kwestii władczego decydowania o przeznaczeniu terenów i określenia warunków ich zagospodarowania ${ }^{33}$. Zarówno bowiem uchwalanie planów miejscowych oraz studium uwarunkowań i kierunków zagospodarowania przestrzennego, jak i wydawanie decyzji o warunkach zabudowy należy zasadniczo do zadań gmin i pozostaje w sferze ustawowo określonych kompetencji jej organów.

Władztwo planistyczne gminy odzwierciedla się zatem w jej kompetencjach do tworzenia prawa (miejscowe plany zagospodarowania przestrzennego), jak i przejawia się w stosowaniu przez jej organy przepisów powszechnie obowiązujących (decyzje w przedmiocie warunków zabudowy i zagospodarowania terenu). System kompetencji gmin w tym zakresie jest na tyle zróżnicowany, że obejmuje również możliwość kształtowania polityki przestrzennej poprzez działania w sferze wewnętrznej, wyrażające się w uchwalaniu dokumentów, które nie stanowią źródeł powszechnie obowiązującego prawa (studia uwarunkowań i kierunków zagospodarowania przestrzennego gmin). W tym właśnie odzwierciedla się władztwo planistyczne gmin, stanowiące rodzaj władztwa administracyjnego. Jak wskazuje W. Jakimowicz, „władztwo planistyczne gminy będące rodzajem władztwa administracyjnego, zawężonym przedmiotowo do planowania przestrzennego, jest określone przez normy ustawowe kreujące kompetencje organów gminy wobec podmiotów zewnętrznych w tym zakresie oraz przez normy ustawowe określające prawa i obowiązki gminy wyznaczające zakres jej samodzielności w realizowaniu władzy publicznej, tj. wyznaczające zakres zadań publicznych w obszarze planowania przestrzennego" ${ }^{34}$. W ten sposób Autor ten opiera zasadę władztwa planistycznego gminy nie tylko na zadaniach publicznych, przyznanych jej do realizacji jako zadania własne, ale także na normach kompetencyjnych, które dla realizacji tych zadań wymagają istnienia konkretnego przepisu upoważniającego do wykonywania tych zadań w określonych formach i zakresie ${ }^{35}$.

${ }^{33}$ Por. Z. Niewiadomski, Planowanie i zagospodarowanie..., s. 30.

34 Tak W. Jakimowicz, O normatywnych...

${ }_{35}$ Zob. rozważania szczegółowe w zakresie kompetencji gmin do podejmowania określonych aktów: W. Jakimowicz, O normatywnych... 
Granice władztwa planistycznego wyznaczają także przepisy ustawy o planowaniu i zagospodarowaniu przestrzennym określające obligatoryjne i fakultatywne elementów treści planów miejscowych czy studiów uwarunkowań i kierunków zagospodarowania przestrzennego gmin, a także przesłanki wydania decyzji o warunkach zabudowy zostały treściowo określone w zróżnicowany sposób, to właśnie bowiem w takich granicach organy te zostały upoważnione do działania w sferze planowania i zagospodarowania przestrzennego. W zależności od instrumentu, a więc czy jest to plan, czy studium, czy decyzja o warunkach zabudowy, stopień szczegółowości wymogów, jakie powinien on spełniać, jest różny i podlega weryfikacji w toku kontroli instancyjnej, a zwłaszcza na etapie kontroli sądowej.

Władztwo to i związana z nim samodzielność gmin w zakresie kształtowania przestrzeni na terytorium objętych ich granicami nie ma charakteru absolutnego i podlega ograniczeniom, wynikającym z jednej strony z ustaw (np. przez przekazanie wojewodom kompetencji nadzorczych ${ }^{36}$ lub wyłączenie $\mathrm{z}$ zakresu zadań gmin upoważnienia do wydawania decyzji o warunkach lokalizacji celu publicznego w odniesieniu do inwestycji na terenach zamkniętych), z drugiej zaś - z konstytucyjnie zakreślonych granic ingerencji w sferę praw i obowiązków innych podmiotów.

Jeśli chodzi o przepisy stanowiące normy ograniczające władztwo planistyczne gminy, wskazać należy w pierwszej kolejności samą ustawę o planowaniu i zagospodarowaniu przestrzennym. Już w art. 4 ust. 1a ustawodawca wskazuje, że w odniesieniu do obszarów morskich wód wewnętrznych, morza terytorialnego i wyłącznej strefy ekonomicznej przeznaczenie terenu, rozmieszczenie inwestycji celu publicznego oraz sposób zagospodarowania i warunki zabudowy terenu określa się na podstawie przepisów ustawy z 21.03.1991 r. o obszarach morskich Rzeczypospolitej Polskiej i administracji mor-

${ }^{36}$ Nadzór jako instytucja prawna $\mathrm{z}$ istotny swej jest immanentnym elementem związanym z decentralizacją zadań publicznych. Zgodnie z art. 172 ust. 1 Konstytucji RP działalność samorządu terytorialnego podlega nadzorowi z punktu widzenia legalności. 
skiej $^{37}$, która to ustawa upoważnia do realizacji tych zadań inne organy. Podobnie z art. 4 ust. 3 u.p.z.p. wynika, że w odniesieniu do terenów zamkniętych w miejscowym planie zagospodarowania przestrzennego ustala się tylko granice tych terenów oraz granice ich stref ochronnych (w tych ostatnich ustala się ograniczenia w zagospodarowaniu i korzystaniu z terenów, w tym zakaz zabudowy). Władztwo planistyczne gmin ograniczają także kompetencje nadzorcze wojewodów oraz normy, które zobowiązują do uzgadniania projektów planów zagospodarowania przestrzennego i studiów uwarunkowań z innymi organami administracji, a także normy, które umożliwiają wprowadzanie zadań administracji rządowej oraz zadań samorządu województw do planów miejscowych ${ }^{38}$. Ograniczenia władztwa planistycznego gmin wynikają ponadto z przepisów szczególnych. Przykładem mogą tu być przepisy z zakresu prawa ochrony środowiska, np.: art. 130 ustawy z 27.04.2001 r. - Prawo ochrony środowiska ${ }^{39}$ czy ograniczenia wynikające z ustawy z 3.02.1995 r. o ochronie gruntów rolnych i leśnych ${ }^{40}$, a także z ustawy z 23.07.2003 r. o ochronie zabytków i opiece nad zabytkami ${ }^{41}$, związane np. z wpisem nieruchomości do rejestru zabytków.

Władztwo planistyczne gmin podlega kontroli sądowej, a jednocześnie samodzielność gmin w zakresie kształtowania ładu przestrzennego, w ramach realizacji przekazanych na jej rzecz zadań publicznych podlega ochronie sądowej. Artykuł 101 u.s.g. stanowi, że każdy, czyj interes prawny lub uprawnienie zostały naruszone uchwałą lub zarządzeniem, podjętymi przez organ gminy w sprawie z zakresu administracji publicznej, może zaskarżyć uchwałę lub zarządzenie do sądu admini-

37 Dz.U. z 2017 r. poz. 2205 ze zm.

${ }_{38}$ Zob. np. art. 15 ust. 3 pkt 4 b u.p.z.p., zgodnie z którym w planie miejscowym w zależności od potrzeb uwzględnia się m.in. granice terenów inwestycji celu publicznego o znaczeniu ponadlokalnym, umieszczonych w planie zagospodarowania przestrzennego województwa lub w ostatecznych decyzjach o lokalizacji drogi krajowej, wojewódzkiej lub powiatowej, linii kolejowej o znaczeniu państwowym, lotniska użytku publicznego, inwestycji w zakresie terminalu lub przedsięwzięcia Euro 2012. Por. Szewczyk [w:] Z. Leoński, M. Szewczyk, M. Kruś, Prawo..., s. 59.

39 Dz.U. z 2018 r. poz. 799 ze zm.

${ }^{40}$ Dz.U. z 2017 r. poz. 1161.

${ }^{41}$ Dz.U. z 2018 r. poz. 2067 ze zm. 
stracyjnego. J. Jakimowicz wskazuje, że: „Okoliczność, że władztwo planistyczne wykonywane w granicach samodzielności gminy opiera się na odkodowanych z obowiązujących przepisów normach zadaniowych obiektywizuje jego charakter, poddając sposób czynienia użytku z tego władztwa pełnej kontroli sądowoadministracyjnej, tak jak pełnej kontroli podlegają procesy wykładni" ${ }^{42}$.

Zasada władztwa planistycznego jako z istoty swej podlegająca ograniczeniom, doznaje także takich ograniczeń w konfrontacji z innymi zasadami systemu prawa charakterystycznymi dla demokratycznego państwa prawa. W szczególności zaś - w konfrontacji z prawami i wolnościami podmiotów prawa, które w związku z zastosowaniem przez gmin władztwa planistycznego jako konstrukcji umożliwiającej ograniczenie sposobu wykonywania prawa własności musi spełniać konstytucyjne standardy wprowadzania tych ograniczeń. Jak wskazuje W. Jakimowicz, ,praktyka uzasadniania ingerencji w prawo własności wyłącznie hasłowo przytaczanym argumentem władztwa planistycznego, bez wyjaśniania jego zakresu i konieczności wykorzystania w takim a nie innym stopniu, jest wynikiem niewłaściwego pojmowania samodzielności gminy" ${ }^{33}$.

Podsumowując, wskazać należy, że z woli ustawodawcy sprawy związane $z$ ładem przestrzennym, a konkretniej - kształtowaniem i prowadzeniem polityki przestrzennej są realizowane w znakomitej części przez jednostki samorządu terytorialnego. W odniesieniu do terenów znajdujących się w granicach gmin sprawy związane w szczególności z uchwalaniem studium uwarunkowań i kierunków zagospodarowania przestrzennego oraz miejscowych planów zagospodarowania przestrzennego, a także wydawaniem decyzji o warunkach zabudowy, zostały przekazane gminom w całości jako zadania w zakresie zaspokajania zbiorowych potrzeb wspólnoty gminnej w sprawach ładu przestrzennego ${ }^{44}$. Na mocy przyznanych kompetencji, objętych kategorią władztwa planistycznego, gmina realizuje zadania związane

\footnotetext{
42 W. Jakimowicz, O normatywnych...

${ }^{43}$ W. Jakimowicz, O normatywnych...

${ }^{44}$ W. Jakimowicz, O normatywnych...
} 
z kształtowaniem przestrzeni, przy czym czyni to w interesie publicznym. Granice władztwa planistycznego gminy wyznaczają zatem $\mathrm{z}$ jednej strony przepisy prawa, w których ustawodawca wprost wskazuje kompetencje gminy służące realizacji zadań związanych z ładem przestrzennym (nie tylko z przepisów prawa planowania i zagospodarowania przestrzennego, ale także z przepisów szczególnych, w tym ochrony środowiska), a z drugiej - inne zasady prawa. W szczególności będzie to zasada działania w interesie publicznym, a szerzej - w celu realizacji dobra wspólnego, gdyż jakakolwiek aktywność gminy pozostająca poza motywacją wynikająca $z$ interesu publicznego nie uzasadnia podejmowania działań w ramach władztwa planistycznego. Odrębną kategorię granic wyznaczają prawa i wolności jednostek, zwłaszcza zaś - prawo własności, którego ograniczenie, realizowane z powołaniem na władztwo planistyczne gminy, wymaga refleksji z punktu widzenia reguł proporcjonalności. Niezależnie od tego część zadań w zakresie kształtowania polityki przestrzennej na obszarze województwa, a więc na szczeblu regionu, ustawodawca przekazał samorządom województwa, w szczególności zobowiązując organy tego samorządu do uchwalania planów zagospodarowania przestrzennego województw. W konsekwencji jednostki samorządu terytorialnego realizują większość zadań państwa z zakresu planowania i zagospodarowania przestrzennego w ramach realizacji zasady decentralizacji władzy publicznej i zadań publicznych.

\section{Bibliografia:}

Bąkowski T., Wplyw przemian ustrojowych $w$ Polsce na prawo zagospodarowania przestrzennego, ST 2000/1-2

Bogucka I., Zagospodarowanie terenów rolniczych w przypadku braku planu miejscowego (zagadnienia wybrane), „Studia Iuridica Agraria” 2012/10

Jagoda J., Sądowa ochrona samodzielności jednostek samorządu terytorialnego, LEX 2011

Jakimowicz W., O normatywnych podstawach władztwa planistycznego gminy [w:] Kierunki reformy prawa planowania i zagospodarowania przestrzennego, red. I. Zachariasz, Warszawa 2012 
Jendrośka J., Teorie samorządu terytorialnego [w:] Prawo administracyjne, red. J. Boć, Wrocław 2004

Kotulski M., Problemy ksztaltowania przestrzeni w procesie planowania i zagospodarowania przestrzennego [w:] Przestrzeń i nieruchomości jako przedmiot prawa administracyjnego. Publiczne prawo rzeczowe, red. I. Niżnik-Dobosz, Warszawa 2012

Kurczewska K., E-partycypacja społeczności lokalnych w planowaniu zagospodarowania przestrzennego [w:] Przestrzeń i nieruchomości jako przedmiot prawa administracyjnego. Publiczne prawo rzeczowe, red. I. Niżnik-Dobosz, Warszawa 2012

Kurowska T., Własność gruntowa a planowanie przestrzenne w dorobku naukowym Profesora Waleriana Pańki, „Studia Iuridica Agraria” 2012/10

Langrod J.S., Instytucje prawa administracyjnego. Zarys części ogólnej, Kraków 2003

Niewiadomski Z., Planowanie i zagospodarowania przestrzenne. Komentarz, Warszawa 2006

Niewiadomski Z., Planowanie przestrzenne. Zarys systemu, Warszawa 2002

Niewiadomski Z., Strębicka D., Zagospodarowanie przestrzenne, Warszawa-Zielona Góra 1994

Ochendowski E., Prawo administracyjne. Część ogólna, Toruń 2004

Parchomiuk J., Nadużycie władztwa planistycznego gminy, ST 2014/4

Pośpiech Ł., Poglądy orzecznictwa sadowoadministracyjnego i doktryny w kwestii studium gminnego i jego charakteru prawnego [w:] Przestrzeń i nieruchomości jako przedmiot prawa administracyjnego. Publiczne prawo rzeczowe, red. I. Niżnik-Dobosz, Warszawa 2012

Prawo zagospodarowania przestrzeni, red. Z. Leoński, M. Szewczyk, M. Kruś, Warszawa 2012

Woźniak M., Interes publiczny jako przesłanka działań organów planistycznych [w:] Przestrzeń i nieruchomości jako przedmiot prawa administracyjnego. Publiczne prawo rzeczowe, red. I. Niżnik-Dobosz, Warszawa 2012 